\title{
COMPOSITION, COMMUNITY STRUCTURE AND VERTICAL DISTRIBUTION OF EPIPHYTIC FERNS ON BAMBOO SPECIES IN BOGOR BOTANIC GARDENS, INDONESIA
}

\author{
Titien Ngatinem Praptosumiryo*, Arief Hidayat, Izu Andry Fijridiyanto, \\ YuPI Isnaini, Didi Usmadi AND Joko Ridho Witono \\ Research Center for Plant Conservation and Botanic Gardens (Bogor Botanic Gardens), \\ Indonesian Institute of Sciences (LIPI). Jl. Ir. H. Juanda No. 13, \\ Bogor 16022, West Java, Indonesia
}

Keywords: Bamboo culm, Fern epiphyte, Distribution, Microhabitat, Species richness

\begin{abstract}
Ecological study of epiphytic ferns growing on bamboo species in Bogor Botanic Gardens, a man-made ecosystem located in a wet lowland area was carried out. The 350 phorophytes of 35 bamboo clumps belonging to 9 species and 3 genera were observed. Each culm was divided into intervals of $1 \mathrm{~m}$ from ground level to a height of $3 \mathrm{~m}$. A total of 1984 individuals belonging to 12 species, nine genera, and six families of epiphytic ferns were recorded, with the highest species richness in Polypodiaceae ( $7 \mathrm{spp}$.). Dendocalamus giganteus Munro was the best host for epiphytic ferns (9 spp.). Two dominant species, Asplenium nidus $\mathrm{L}$. and Davallia denticulata (Burm.f.) Mett. ex Kuhn with the same frequency value (97.14\%), and relative species abundance of 31.49 individuals per clump and 14.94 individuals per clump, showed the highest Importance Value Index (IVI) of 83.19 and $54.00 \%$, respectively. The first one-meter level of bamboo culms hosted all the species. Pyrrosia piloselloides (L.) Price was the only species that grew until the highest intervals of height with a decreasing frequency from the bottom.
\end{abstract}

\section{Introduction}

Epiphytes are vascular and non-vascular plants that live on other plants, but they do not gain nutrient or water supply directly from the host (Kress 1986). Some species of epiphytic plants play a very important role in biogeochemical processes, provide favorable microsites for free-living nitrogen-fixing bacteria (Brighicna et al. 1992), increase the retention of water derived from precipitation (Veneklaas and Van Ek 1990), contribute to primary productivity, litterfall, and nutrient cycling due to their high growth efficiency, including leaf production and root growth (Putz 1983).

Epiphytic plants comprise about $10 \%$ of all vascular plants and are particularly abundant and diverse in the wet tropics. These epiphytic plants are mainly distributed within angiosperms and ferns. A total of 2,593 epiphytic species of 92 genera of ferns and fern-allies were recorded in the world (Nieder et al. 2001). However, the ecology of many epiphytic species is poorly understood especially in the wet tropic regions (Adubasim et al. 2018). In addition, presently most studies on the ecology, floristic, and diversity of epiphytic ferns were reported from Brazil (Machado et al. 2016), Mexico (Jiménez-López et al. 2020), French Polynesia (Nitta et al. 2020), and Peninsular Malaysia (Zhang et al. 2010). Studies dealing with the assessment of host variability and their composition for epiphytic ferns have been reported everywhere. Epiphytic ferns can inhabit a wide variety of flowering trees and tree ferns (Einzmann et al. 2015, Parashurama et al. 2016). However, an epiphytic symbiosis between ferns and bamboo has not been reported yet either in the natural and man-made ecosystem, such as botanic gardens.

*Author for correspondence: < tienpferns@gmail.com>. 
Bamboo has unique features that distinguish it from most other woody plants. Bamboo culms are connected by an extensive system of rhizomes leading to emerging new culms by rapid vegetative reproduction (Jansen 1976). Bamboos are included in the fastest-growing plants in the world and tolerance for marginal land, therefore bamboo is a good candidate for afforestation and in mitigating climate change impacts through carbon sequestration (Terefe et al. 2019). Bamboo culms may have the potential to be an epiphyte host species for ferns in the wet tropical forests although they have no bark as on the other tree plants. Many species of bamboo may give rise thick aerial roots at lower nodal region creating microhabitat for epiphytic ferns.

The present study aimed to figure out the floristic composition, community structure, and vertical distribution of epiphytic ferns on bamboo species in the Bogor Botanic Gardens. This is the first report on the ecological study of epiphytic ferns growing on bamboo species in the Gardens. This research was conducted in order to answer three questions, i.e. (i) how do species richness and composition of ferns epiphytes vary over host bamboo culms? (ii) how do these species' richness and composition patterns correlate with host characteristics and environmental factors? and (iii) how do ferns epiphytes distribute vertically over host bamboo culms?

\section{Materials and Methods}

The present study was conducted from December 2020 to April 2021 in Bogor Botanic Gardens (BBG), Indonesia (Fig. 1). The garden has maintained 12,370 specimens belonging to 3,555 species, 1,202 genera, and 191 families of vascular plants (Ariati et al. 2019). BBG is covering an area of $87 \mathrm{ha}$. at an altitude of $215-250 \mathrm{~m}$ asl. and topography is relatively flat with a slope of $3-15 \%$ and $16-31 \%$ near the river bank (Santosa et al. 2014). According to the Koppen climate classification (Köppen 1936), BBG climate belongs to the Wet Tropical Climate type (Af) with an average temperature of $26^{\circ} \mathrm{C}$, the lowest and highest temperature is 21.4 and $30.4^{\circ} \mathrm{C}$, respectively. The humidity is more than $70 \%$, and the monthly rainfall ranges from $250-330 \mathrm{~mm}$. The annual rainfall varies between $3000-5000 \mathrm{~mm}$, with more than 240 rainy days and the highest rainfall occurs in December and January every year (Santosa et al. 2014).

Thirty-five bamboo clumps of 28-48 years old belonging to nine species of three genera planted in eight collection sites were surveyed (Fig. 1). The 10 sampled were culms for each clump purposively to count sporelings and sporophytes of the epiphytic ferns. Epiphytic ferns were recorded from the basal culms to a height of $3 \mathrm{~m}$. Each culm was divided into intervals of 1 $\mathrm{m}$ from ground level to a height of $3 \mathrm{~m}$, thus obtaining 1050 one-meter samples of the epiphytic fern community on culms stratified according to height. The species determination methods of Holttum (1966) and Hovenkamp et al. (1998) were followed. To ensure accurate species identification for sporelings of the epiphytes, only sporelings with the minimal sizes of ca. $10 \mathrm{~mm}$ length and ca.5 mm wide were recorded (Fig. 2). Definition for epiphytic classification followed Zotz (2016), whereas the classification system followed Smith et al. (2008).

Host culm height and diameter at breast height (dbh) were recorded using a digital forestry range finder (Nikon Forestry Pro Waterproof $6 \times 126.0^{\circ}$ ) and diameter tape, respectively. Other characteristics and environmental variables measured at each bamboo clumps were the numbers of bamboo reeds/clumps, temperature, humidity, light intensity, canopy cover, and direction overgrown. Canopy covers and direction overgrown were estimated using Canopy Cover Free using android device's camera and Compass of Google Play Applications, respectively, 


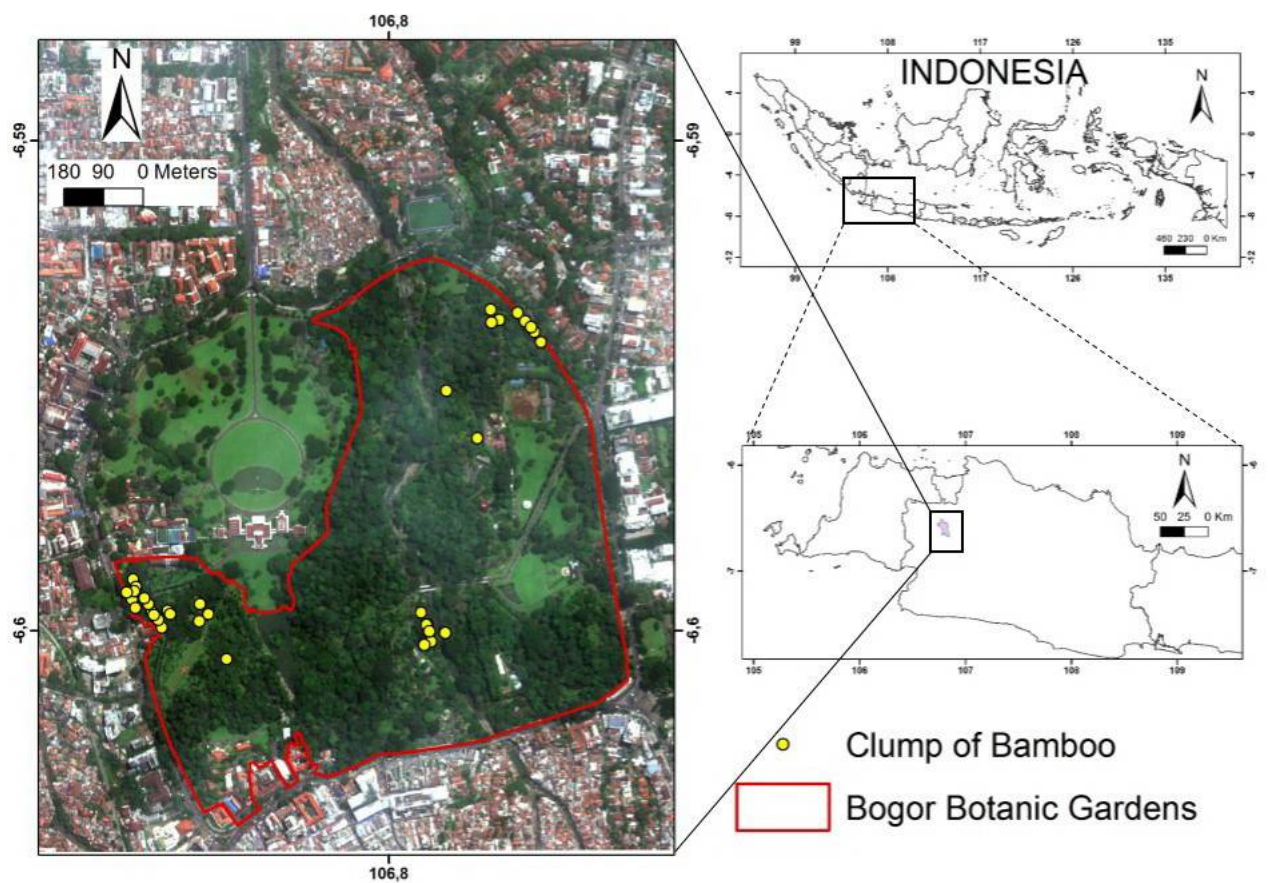

Fig. 1. Map of Bogor Botanic Gardens. Yellow circles are showing eight locations of the 35 clumps belonging to 9 bamboo species observed.

The fern vegetation data were analyzed quantitatively, by abundance, frequency, relative density, relative frequency, and Important Value Index (IVI) (Curtis and McIntosh 1950) by the following equation:

$$
\begin{aligned}
& \text { Relative Density }=\frac{\text { Number of individuals of species }}{\text { Total number of individuals of all species }} \times 10 \mathrm{C} \\
& \text { Relative Frequency }=\frac{\text { Frequeny of species }}{\text { Sum of frequency values for all species }} \times 100
\end{aligned}
$$

The IVI was calculated by adding the relative density and relative frequency values. Analysis of the diversity of epiphytic ferns growing on bamboo using several diversity indices, namely Margalef richness index $\left(\mathrm{D}_{\mathrm{mg}}\right)$, Shannon diversity index $\left(\mathrm{H}^{\prime}\right)$, and Buzas and Gibson's evenness index (E) with the following equation:

$$
\begin{aligned}
& D_{m g}=\begin{array}{l}
S-1 \\
\ln N
\end{array} \\
& H^{\prime}=-\sum_{i=1}^{m}\left[\left(\frac{n_{i}}{N}\right) \ln \left(\frac{n_{i}}{N}\right)\right] \\
& E=\frac{e^{H^{k}}}{S}
\end{aligned}
$$

Where: $\mathrm{D}_{\mathrm{mg}}=$ Margalef richness index, $\mathrm{N}=$ Total number of individuals of all species, $\mathrm{S}=$ Number of all species, $\mathrm{H}^{\prime}=$ Shannon diversity index, $\mathrm{ni}=$ Number of individuals of each species, 
$\mathrm{E}=$ Buzas and Gibson's evenness index, e=Natural logarithm base (Buzas and Gibson 1969, Magurran 2004).

Variations of fern abundance, diversity indices, and environmental variables in each bamboo clump were analyzed after using Analysis of Variance (ANOVA). For significantly different variables, it was followed by Duncan's multiple range test (DMRT). Ordination analysis was used to determine the relationship between the abundance of epiphytic ferns and environmental variables using Canonical Correspondence Analysis (CCA). Diversity index analysis, analysis of variance, and Canonical Correspondence Analysis were calculated using Paleontological Statistics (PAST) version 3.26 (Hammer et al. 2001).

\section{Results and Discussion}

A total of 1984 individuals belonging to 12 epiphytic fern species under eight genera and six families were recorded (Fig. 2 and Table 1). The floristic composition of the epiphyte community is similar to those found on palm trees growing in BBG with 16 species of epiphytic ferns and lycopods (Praptosuwiryo et al. 2019). The highest species richness was recorded in Polypodiaceae with seven species. The dominance of the Polypodiaceae is a common trend in wet tropical epiphyte communities.

Previous publications stated that the epiphytic ferns flora holo-epiphytes are usually predominant (Fraga et al. 2008 and Schneider and Schmitt 2011) in Brazil; and Praptosuwiryo et al. (2019) in BBG. Some epiphytes also grow occasionally on rocks, such as Belvisia mucronata and Microsorum scolopendria (Hovenkamp et al. 1998), or soil such as Nephrolepis biserrata (Xing et al. 2013) and Psilotum nudum (Zhang and Yatskievych 2013). Pyrrosia piloselloides is also a facultative mild-hemiparasitic epiphyte (Tsutsumi et al. 2018).

Abundance is the average number of individuals of a species in an observation plot area (Curtis and McIntosh 1950). The abundance of ferns growing on bamboo clumps was 56.69 individuals/clump on average, with a range from 0.03 to 31.49 individuals per clump (Table 2.). Asplenium nidus and D. denticulata had the highest abundance, viz. 31.49 individuals per clump and 14.94 individuals per clump, respectively. Most of the species showed low abundance, such as $P$. lanceolata, $M$. scolopendria, M. punctatum, P. nudum, G. percussum, and B. mucronata.

The range of frequency values of epiphytic ferns growing on bamboo clumps species was $2.87-97.14 \%$ (Table 2). Asplenium nidus and $D$. denticulata had the highest frequency as the two species were found in 34 clumps of 35 bamboo clumps observed. Another species with the high frequency was $P$. piloselloides, it could be found growing well on 18 clumps. According to Dajoz (1977), A. nidus, D. denticulata, and P. piloselloides have a constant distribution in the study site $(50 \% \leq \mathrm{F}<100 \%)$. V. ensiformis has a common distribution $(25 \% \leq \mathrm{F}<50 \%)$, seven species come into the category a by-catch distribution $(5 \% \leq<25 \%)$, and two species, namely $G$. percussum and B. mucronata have a rare distribution $(\mathrm{F}<5 \%)$.

The level of importance of a species in the community can be seen from the IVI value (Schneider and Schmitt 2011). Epiphytic fern species with the highest IVI was found in A. nidus, followed by D. denticulata, P. piloselloides, and Vittaria ensiformis with IVI of 83.19, 54.00, 21.04 and $16.66 \%$, respectively. These three species have a high density and are evenly distributed over various species of bamboo clumps. Other eight species of ferns have low IVI $(<10 \%)$ (Table 2.). This indicated that the role of these species in the fern community of the bamboo clumps is low. They generally have a low density and were only found in certain bamboo clump habitats. Species that have a low IVI need more concrete conservation efforts for these species to be sustainable. 

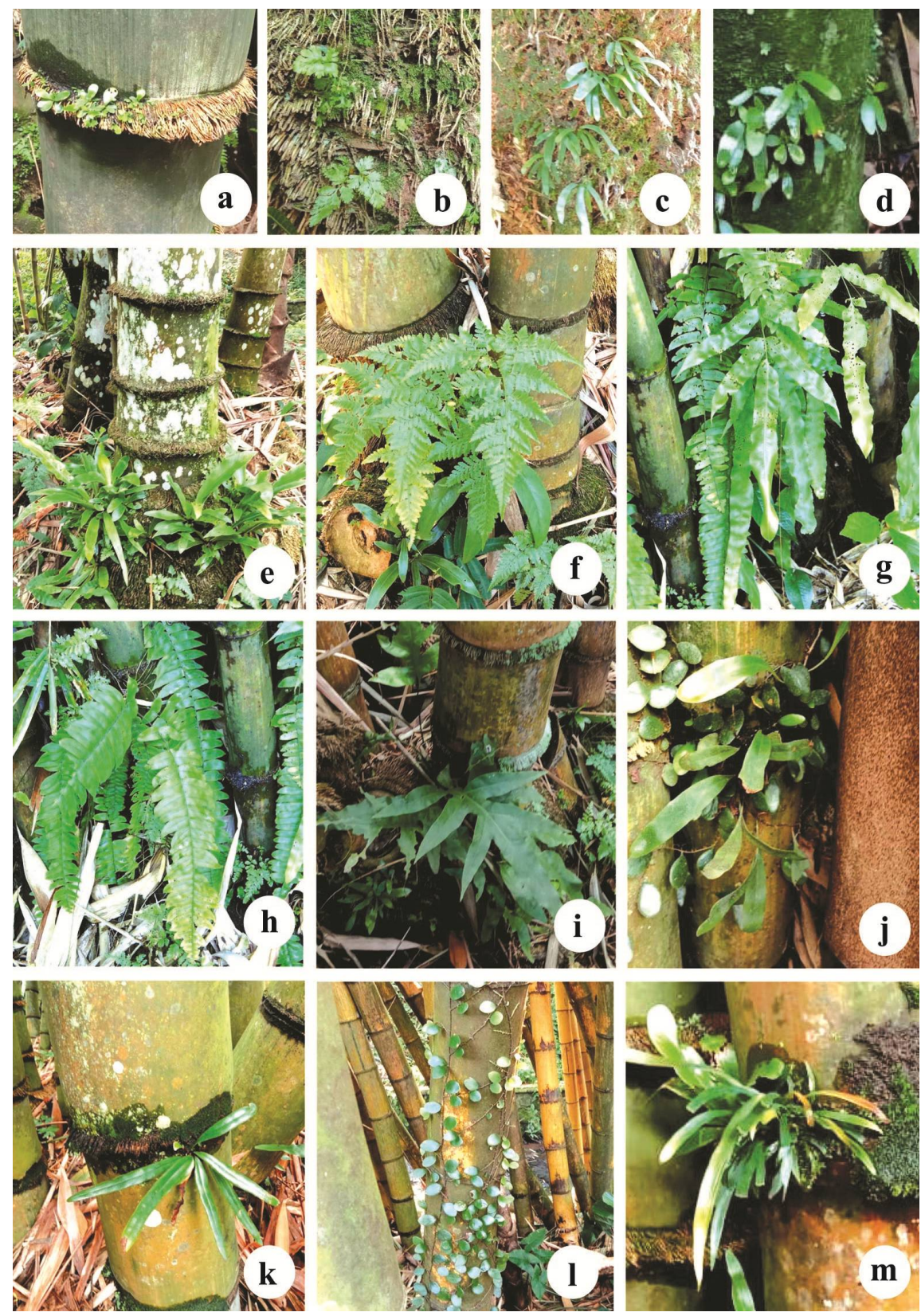

Fig. 2. Ferns epiphyte growing on bamboo culms in Bogor Botanic Gardens. a - d. Sporelings of epiphytic ferns. a. Asplenium nidus on the node of Dendrocalamus giganteus; b-c. Davallia denticulata and Vittaria ensiformis, respectively, perching on aerial roots of $D$. asper; d. Pyrrosia longifolia on the internode of $D$. asper. e - m. Young sporophytes. e. A. nidus on the aerial roots of D. asper; f. Davallia denticulata on aerial roots of D. giganteus; g-h Goniophlebium percussum and Nephrolepis biserrata on node and internode of Gigantochloa apus, respectively; i. Microsorum punctatum on the aerial root of D. giganteus; j. Pyrrosia lanceolata on the node and internode of G. atter; k. Pyrrosia longifolia on the node of D. giganteus; 1 . Pyrrosia. piloselloides on the internode of Bambusa vulgaris; $\mathrm{m}$. Vittaria ensiformis on the node of D. giganteus. 
Table 1. Floristic composition, lifeform, habitat, perching site, and host plants of epiphytic ferns growing on bamboo culms species planted in Bogor Botanic Gardens.

\begin{tabular}{|c|c|c|c|c|c|c|}
\hline No. & $\begin{array}{l}\text { Family } \\
\text { and species }\end{array}$ & $\begin{array}{l}\text { Lifeform } \\
\text { /rhizome }\end{array}$ & $\begin{array}{l}\text { Ecological } \\
\text { category }\end{array}$ & $\begin{array}{l}\text { Perching } \\
\text { sites }\end{array}$ & $\begin{array}{l}\Sigma \text { Indi- } \\
\text { vidual }\end{array}$ & Host plants \\
\hline 1. & $\begin{array}{l}\text { Aspleniaceae } \\
\text { Asplenium nidus L. }\end{array}$ & $\begin{array}{l}\text { Short } \\
\text { uprigt }\end{array}$ & HAB & RB, ND & 1102 & $\begin{array}{l}(1),(2),(3),(4), \\
(5),(6),(7),(8),(9)\end{array}$ \\
\hline \multicolumn{7}{|c|}{ Davalliaceae } \\
\hline 2. & $\begin{array}{l}\text { Davallia denticulata } \\
\text { (Burm.) Mett. ex Kuhn }\end{array}$ & $\begin{array}{l}\text { Long } \\
\text { creeping }\end{array}$ & HAB & RB, ND & 523 & $\begin{array}{l}\text { 1), (2), (3), (4), (5), } \\
(6),(7),(8),(9)\end{array}$ \\
\hline . & Nephrolepidaceae & & & & & \\
\hline 3. & $\begin{array}{l}\text { Nephrolepis biserrata } \\
\text { (Sw.) Schott }\end{array}$ & $\begin{array}{l}\text { Long } \\
\text { creeping }\end{array}$ & HMP & $\mathrm{RB}, \mathrm{ND}$ & 32 & $(3),(4),(6),(8)$ \\
\hline \multicolumn{7}{|c|}{ Polypodiaceae } \\
\hline 4. & $\begin{array}{l}\text { Belvisia mucronata (Fée) } \\
\text { Copel. }\end{array}$ & $\begin{array}{l}\text { Short } \\
\text { creeping }\end{array}$ & $\mathrm{HAB}$ & ND & 1 & (4) \\
\hline 5. & $\begin{array}{l}\text { Goniophlebium percussum } \\
\text { (Cav.) Wagner \& Grether }\end{array}$ & $\begin{array}{l}\text { Long } \\
\text { creeping }\end{array}$ & HAB & $\mathrm{RB}, \mathrm{ND}$ & 3 & (6) \\
\hline 6. & $\begin{array}{l}\text { Microsorum scolopendria } \\
\text { (Burm. f.) Copel. }\end{array}$ & $\begin{array}{l}\text { Long } \\
\text { creeping }\end{array}$ & HAB & $\mathrm{RB}$ & 9 & (2), (4) \\
\hline 7. & $\begin{array}{l}\text { Microsorum punctatum } \\
\text { (L.) Copel. }\end{array}$ & $\begin{array}{l}\text { Short } \\
\text { creeping }\end{array}$ & HAB & $\mathrm{RB}, \mathrm{ND}$ & 9 & (2) \\
\hline 8. & $\begin{array}{l}\text { Pyrrosia lanceolata (L.) } \\
\text { Farw. }\end{array}$ & $\begin{array}{l}\text { Long } \\
\text { creeping }\end{array}$ & HAB & ND, IN & 9 & $(2),(5),(6),(7)$ \\
\hline 9. & $\begin{array}{l}\text { Pyrrosia longifolia (N. L. } \\
\text { Burman) Morton }\end{array}$ & $\begin{array}{l}\text { Long } \\
\text { creeping }\end{array}$ & HAB & ND & 27 & $(2),(4),(8)$ \\
\hline 10. & $\begin{array}{l}\text { Pyrrosia piloselloides (L.) } \\
\text { Price }\end{array}$ & $\begin{array}{l}\text { Long } \\
\text { creeping }\end{array}$ & HAB & $\begin{array}{l}\mathrm{RB}, \mathrm{ND}, \\
\text { IN }\end{array}$ & 127 & $\begin{array}{l}\text { 1), (2), (3), (4), (5), } \\
(7),(8),(9)\end{array}$ \\
\hline 11. & Psilotaceae & Short-to & FAC & $\mathrm{RB}$ & & \\
\hline & $\begin{array}{l}\text { Psilotum nudum (L.) Pal. } \\
\text { Beauv. }\end{array}$ & $\begin{array}{l}\text { long } \\
\text { creeping, }\end{array}$ & & & 5 & (4) \\
\hline \multicolumn{7}{|c|}{ Pteridaceae } \\
\hline 12. & Vittaria ensiformis Swartz. & $\begin{array}{l}\text { Short- } \\
\text { creeping }\end{array}$ & HAB & $\begin{array}{l}\mathrm{RB} / \mathrm{ND} / \\
\mathrm{IN}\end{array}$ & 137 & $(2),(3),(4),(5),(8)$ \\
\hline & $\begin{array}{l}\text { Total } 12 \text { species; } \\
9 \text { genera; } 6 \text { families }\end{array}$ & & & & 1984 & \\
\hline
\end{tabular}

Host plants: (1) Bambusa vulgaris Schrad.; (2) Dendrocalamus asper (Schult.) Backer; (3) Dendrocalamus brandisii (Munro) Kurz; (4) Dendocalamus giganteus Munro; (5) Dendrocalamus latiflorus Munro; (6) Gigantochloa apus (Schult.) Kurz; (7) Gigantochloa atter (Hassk.) Kurz; (8) Gigantochloa robusta Kurz.; (9) Gigantochloa verticillata (Willd.) Munro. $\mathrm{HAB}=$ habitual holoepiphytes; $\mathrm{FAC}=$ facultative holoepiphytes; $\mathrm{HMP}=$ Primary emiepiphytes; Perching Site: $\mathrm{RB}=$ Aerial roots of basal culm, ND= nodus, $\mathrm{IN}=$ internodes. 
Table 2. Community structure of epiphytic ferns sampled on bamboo species in Bogor Botanic Gardens, West Java, Indonesia, in decreasing order by Value Index (IVI). D = Density (Individuals/Clump); F = Frequency; RD = Relative Density; RF = Relative Frequency; IVI = Important Value Index.

\begin{tabular}{llccccc}
\hline No & \multicolumn{1}{c}{ Species } & $\begin{array}{c}\mathrm{D} \\
\text { (indv./clump) }\end{array}$ & $\begin{array}{c}\mathrm{F} \\
(\%)\end{array}$ & $\begin{array}{c}\mathrm{RD} \\
(\%)\end{array}$ & $\begin{array}{c}\mathrm{RF} \\
(\%)\end{array}$ & $\begin{array}{c}\text { IVI } \\
(\%)\end{array}$ \\
\hline 1 & & 31.49 & 97.14 & 55.54 & 27.64 & 83.19 \\
2 & Asplenium nidus L. & 14.94 & 97.14 & 26.36 & 27.64 & 54.00 \\
3 & Davallia denticulata (Burm.) Mett. ex Kuhn & 3.63 & 51.43 & 6.40 & 14.63 & 21.04 \\
4 & Pyrrosia piloselloides (L.) Price & 3.91 & 34.29 & 6.91 & 9.76 & 16.66 \\
5 & Nephrolepis biserrata (Sw.) Schott & 0.91 & 22.86 & 1.61 & 6.50 & 8.12 \\
6 & Pyrrosia longifolia (N. L. Burman) Morton & 0.77 & 11.43 & 1.36 & 3.25 & 4.61 \\
7 & Pyrrosia lanceolata (L.) Farw. & 0.26 & 11.43 & 0.45 & 3.25 & 3.71 \\
8 & Microsorum scolopendria (Burm. f.) Copel. & 0.26 & 8.57 & 0.45 & 2.44 & 2.89 \\
9 & Microsorum punctatum (L.) Copel. & 0.26 & 5.71 & 0.45 & 1.63 & 2.08 \\
10 & Psilotum nudum (L.) Pal. Beauv. & 0.14 & 5.71 & 0.25 & 1.63 & 1.88 \\
11 & Goniophlebium percussum (Cav.) Wagner \& & 0.09 & 2.86 & 0.15 & 0.81 & 0.96 \\
& Grether & & & & & \\
12 & Belvisia mucronata (Fée) Copel. & 0.03 & 2.86 & 0.05 & 0.81 & 0.86 \\
\hline
\end{tabular}

The Abundance of some species and diversity indices in each bamboo clump have varying values (Table 3). The one-way ANOVA test revealed that the abundance, number of species, richness, diversity and evenness index of ferns among the nine bamboo clumps were not significantly different $(\mathrm{P}>0.05)$. Based on the number of epiphytic fern species growing in the bamboo clumps, the highest occurred on Dendrocalamus giganteus clump with an average of 4.13 \pm 1.25 species, meanwhile, Gigantochloa verticillata clump had the lowest with an average $2.33 \pm$ 0.58 species.

Dendrocalamus brandisii and D. giganteus clumps displayed the greatest abundance of epiphytic ferns with values of $120.50 \pm 53.03$ and $82.75 \pm 63.08$ individuals/clump, respectively, while their species richness was relatively even. The lowest epiphytic fern abundance occurred on Gigantochloa apus clumps with an abundance value of $19.40 \pm 20.22$ individuals/clump. The high abundance of ferns in $D$. brandisii is probably due to the characteristic factors of the bamboo. Dendrocalamus brandisii has stems that are smooth, straight, without spines, and a trunk height of about 25-30 m with a diameter of 13-30 cm (Viswanath et al. 2013). This study revealed that $D$. brandisii has the highest number of culms per clump compared to other species, of $186.50 \pm 37.48$ culms per clump with an average culm height of $19.65 \pm 1.77 \mathrm{~m}$ and $13.49 \pm 2.38 \mathrm{~cm}$ in diameter. The high number of culms in one clump causes a large amount of water to be trapped in the bamboo culms, roots, and rhizomes. This resulted in fairly high water availability in the bamboo clumps which supported spore germination and the growth of ferns. Ferns are very sensitive to water availability and drought (Benzing 1998). A large number of culm also represents more habitat partitioning and more available space for spore interception, colonization, and biomass development. These results are in line with the widely documented dependence of epiphyte proliferation on tree size (Zotz and Vollrath 2003). 
Table 3. Abundance, number of species, and diversity indices of epiphytic ferns community sampled on bamboo clumps in Bogor Botanic Gardens.

\begin{tabular}{llccccc}
\hline No. & Bamboo clumps & $\mathrm{A}$ & $\mathrm{S}$ & $\mathrm{D}_{\mathrm{mg}}$ & $\mathrm{H}^{\prime}$ & $\mathrm{E}$ \\
\hline 1 & Bambusa vulgaris Schrad. & $35.50 \pm 19.09$ & $2.50 \pm 0.71$ & $0.41 \pm 0.14$ & $0.63 \pm 0.64$ & $0.79 \pm 0.28$ \\
2 & Dendrocalamus asper (Schult.) Backer & $78.00 \pm 54.08$ & $3.86 \pm 1.46$ & $0.68 \pm 0.28$ & $0.87 \pm 0.42$ & $0.67 \pm 0.06$ \\
3 & $\begin{array}{l}\text { Dendrocalamus brandisii (Munro) } \\
\text { Kurz }\end{array}$ & $120.50 \pm 53.03$ & $4.00 \pm 0.00$ & $0.64 \pm 0.06$ & $0.96 \pm 0.32$ & $0.67 \pm 0.21$ \\
4 & Dendrocalamus giganteus Munro & $82.75 \pm 63.08$ & $4.13 \pm 1.25$ & $0.74 \pm 0.26$ & $0.86 \pm 0.51$ & $0.63 \pm 0.18$ \\
5 & Dendrocalamus latiflorus Munro & $42.33 \pm 12.66$ & $4.00 \pm 1.73$ & $0.79 \pm 0.41$ & $1.03 \pm 0.34$ & $0.75 \pm 0.10$ \\
6 & Gigantochloa apus (Schult.) Kurz & $19.40 \pm 20.22$ & $3.20 \pm 1.79$ & $0.81 \pm 0.34$ & $0.74 \pm 0.44$ & $0.74 \pm 0.12$ \\
7 & Gigantochloa atter (Hassk.) Kurz & $37.00 \pm 26.87$ & $3.00 \pm 1.41$ & $0.64 \pm 0.55$ & $0.87 \pm 0.36$ & $0.84 \pm 0.11$ \\
8 & Gigantochloa robusta Kurz. & $24.33 \pm 20.21$ & $3.00 \pm 1.00$ & $0.67 \pm 0.11$ & $0.77 \pm 0.31$ & $0.75 \pm 0.03$ \\
9 & Gigantochloa verticillata (Willd.) & $29.67 \pm 31.00$ & $2.33 \pm 0.58$ & $0.45 \pm 0.08$ & $0.60 \pm 0.22$ & $0.80 \pm 0.05$ \\
& Munro & 0.108 & 0.539 & 0.675 & 0.956 & 0.387 \\
\hline
\end{tabular}

$\mathrm{A}=$ Abundance (indv./clump); $\mathrm{S}=$ Number of species; $\mathrm{D}_{\mathrm{mg}}=$ Margalef's richness index; $\mathrm{H}^{\prime}=$ Shannon's diversity index; $\mathrm{E}$ $=$ Buzas and Gibson's evenness index.

The abundance of epiphytic species has a positive correlation with DBH of host species, where an increase in DBH of host species will increase the availability of space for the epiphyte plants to attach and grow (Magalhães and Lopes 2015). In this study, D. brandisii has the second highest culm diameter after $D$. giganteus. The larger diameter of the bamboo culms allows more space for the interception and germination of spores, as well as the colonization of the sporophyte of epiphytic ferns.

Margalef's richness index of ferns growing in bamboo clumps has an average value of 0.410.81. Based on the species richness categories of Magurran (2004), it was concluded that the species richness of epiphytic ferns growing on bamboo clumps was classified into low richness. The value of the Shannon's diversity index on nine species of bamboo clumps was an average of 0.60-1.03. The value of Shannon's diversity index based on category by Schneider and Schmitt (2011) fern diversity in bamboo clumps is mostly included in the low category $\left(0<\mathrm{H}^{\prime}<1\right)$ and only one location has a moderate diversity $\left(1<\mathrm{H}^{\prime}<3\right)$. The low value of Margalef's richness and Shannon's diversity is because only a few ferns can live attached to bamboo clumps and bamboo is a specific habitat, so not all ferns can grow in that habitat. The low value of richness and diversity indicates that the fern community in the bamboo clump is unstable and susceptible to disturbance.

Buzas and Gibson's evenness analysis of ferns growing in bamboo clumps resulted in an average value of $0.63-0.84$. The evenness of epiphytic ferns on bamboo species came into a high evenness $(E \geq 0.6)$. A high eveness value indicates that the number of individuals in each species of ferns tends to be evenly distributed or there is no species of fern that dominates in the bamboo clump habitat, although there are some species of fern with a high abundance compared to the other species.

The one-way ANOVA test showed that the variables of temperature, humidity, canopy cover, and direction of growth where the epiphytic plants were perched on were not significantly different. Meanwhile, the parameters of height, diameter, number of culms, and light intensity differed significantly between bamboo clumps. Therefore, these parameters were used in the CCA. 
Epiphytic ferns tend to inhabit the bamboo clumps with a range size of culms of 14.49-26.26 m height and 7.91-17.24 cm diam., 47.14-186.50 culms per clump, and providing a canopy opening for the light intensity range of 470.17-7113.00 lux (Table 4, Fig. 3).

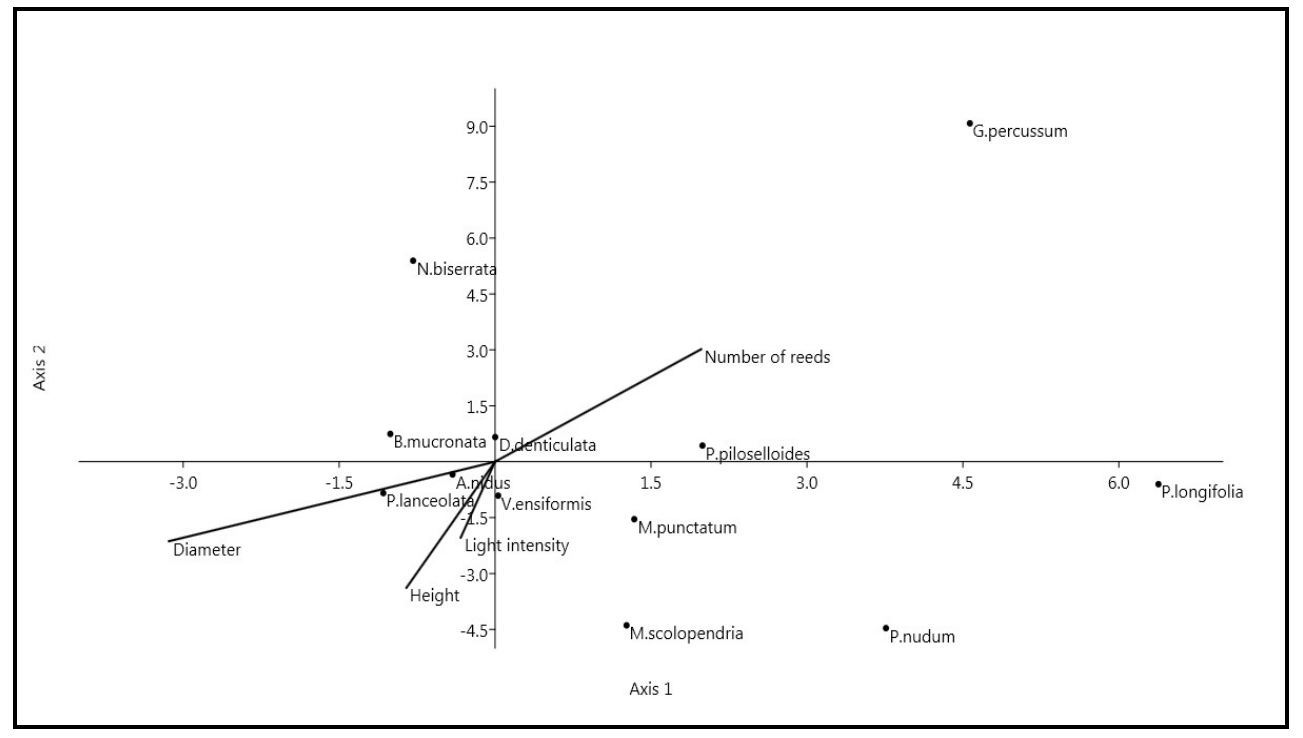

Fig. 3. Ordination diagram for Canonical Correspondence. Analysis of the abundance of fern and environmental variables.

Table 4. Characteristics of bamboo clumps and environmental variables for the epiphytic fern community in the Bogor Botanic Gardens.

\begin{tabular}{|c|c|c|c|c|c|c|}
\hline No. & Bamboo clumps & $\begin{array}{l}\text { Height } \\
(\mathrm{m})\end{array}$ & $\begin{array}{l}\text { Diameter } \\
(\mathrm{cm})\end{array}$ & $\begin{array}{l}\text { Number of } \\
\text { reeds/culms }\end{array}$ & $\begin{array}{l}\text { Temperature } \\
\left({ }^{0} \mathrm{C}\right)\end{array}$ & $\begin{array}{l}\text { Humidity } \\
\text { (\%) }\end{array}$ \\
\hline 1 & Bambusa vulgaris Schrad. & $14.49 \pm 1.07^{\mathrm{a}}$ & $8.70 \pm 1.34^{\mathrm{a}}$ & $166.00 \pm 114.55^{\mathrm{bc}}$ & $29.10 \pm 1.98$ & $68.55 \pm 7.14$ \\
\hline 2 & $\begin{array}{l}\text { Dendrocalamus asper (Schult.) } \\
\text { Backer }\end{array}$ & $18.75 \pm 3.92^{\mathrm{ab}}$ & $12.60 \pm 2.48^{\mathrm{abc}}$ & $47.14 \pm 24.53^{\mathrm{a}}$ & $25.60 \pm 4.63$ & $78.78 \pm 3.77$ \\
\hline 3 & $\begin{array}{l}\text { Dendrocalamus brandisii } \\
\text { (Munro) Kurz }\end{array}$ & $19.65 \pm 1.77^{\mathrm{ab}}$ & $13.49 \pm 2.38^{\mathrm{abc}}$ & $186.50 \pm 37.48^{\mathrm{c}}$ & $27.28 \pm 0.53$ & $74.87 \pm 0.47$ \\
\hline 4 & $\begin{array}{l}\text { Dendrocalamus giganteus } \\
\text { Munro }\end{array}$ & $26.26 \pm 7.09^{b}$ & $16.14 \pm 1.51^{\mathrm{bc}}$ & $128.75 \pm 56.89^{\mathrm{bc}}$ & $27.01 \pm 0.71$ & $77.53 \pm 3.31$ \\
\hline 5 & $\begin{array}{l}\text { Dendrocalamus latiflorus } \\
\text { Munro }\end{array}$ & $22.48 \pm 7.75^{\mathrm{ab}}$ & $12.96 \pm 1.59^{\mathrm{abc}}$ & $59.67 \pm 28.36^{\mathrm{a}}$ & $29.37 \pm 2.15$ & $71.60 \pm 8.47$ \\
\hline 6 & $\begin{array}{l}\text { Gigantochloa apus (Schult.) } \\
\text { Kurz }\end{array}$ & $16.92 \pm 2.19^{\mathrm{ab}}$ & $7.91 \pm 1.55^{\mathrm{a}}$ & $171.00 \pm 63.97^{\mathrm{bc}}$ & $27.73 \pm 1.42$ & $78.48 \pm 4.87$ \\
\hline 7 & $\begin{array}{l}\text { Gigantochloa atter (Hassk.) } \\
\text { Kurz }\end{array}$ & $16.79 \pm 2.38^{\mathrm{ab}}$ & $7.91 \pm 0.28^{\mathrm{a}}$ & $84.50 \pm 58.69^{\mathrm{ab}}$ & $27.80 \pm 0.14$ & $77.25 \pm 4.73$ \\
\hline 8 & Gigantochloa robusta Kurz. & $23.70 \pm 6.52^{\mathrm{ab}}$ & $10.42 \pm 0.50^{\mathrm{ab}}$ & $65.33 \pm 35.57^{\mathrm{a}}$ & $27.23 \pm 0.46$ & $72.18 \pm 5.59$ \\
\hline 9 & $\begin{array}{l}\text { Gigantochloa verticillata } \\
\text { (Willd.) Munro }\end{array}$ & $23.02 \pm 2.17^{\mathrm{ab}}$ & $17.24 \pm 9.40^{\mathrm{c}}$ & $116.33 \pm 37.02^{\mathrm{abc}}$ & $29.37 \pm 3.70$ & $73.88 \pm 17.42$ \\
\hline \multicolumn{2}{|c|}{ P Value } & 0.045 & 0.001 & 0.004 & 0.484 & 0.493 \\
\hline
\end{tabular}


Contd.

\begin{tabular}{lllll}
\hline No. & \multicolumn{1}{c}{ Bamboo clumps } & $\begin{array}{c}\text { Light intensity } \\
(\mathrm{lux})\end{array}$ & $\begin{array}{c}\text { Canopy cover } \\
(\%)\end{array}$ & $\begin{array}{c}\text { Direction overgrown } \\
\left({ }^{0}\right)\end{array}$ \\
\hline 1 & Bambusa vulgaris Schrad. & $7113.00 \pm 8751.86^{\mathrm{b}}$ & $41.67 \pm 5.99$ & $175.00 \pm 155.56$ \\
2 & Dendrocalamus asper (Schult.) Backer & $1121.09 \pm 908.74^{\mathrm{a}}$ & $45.56 \pm 4.56$ & $167.86 \pm 33.39$ \\
3 & Dendrocalamus brandisii (Munro) Kurz & $700.50 \pm 453.26^{\mathrm{a}}$ & $49.54 \pm 0.96$ & $109.50 \pm 28.99$ \\
4 & Dendrocalamus giganteus Munro & $1616.31 \pm 1642.78^{\mathrm{a}}$ & $39.77 \pm 14.72$ & $157.38 \pm 73.84$ \\
5 & Dendrocalamus latiflorus Munro & $470.17 \pm 373.59^{\mathrm{a}}$ & $39.51 \pm 26.56$ & $171.00 \pm 59.19$ \\
6 & Gigantochloa apus (Schult.) Kurz & $863.10 \pm 1019.10^{\mathrm{a}}$ & $46.19 \pm 11.62$ & $129.40 \pm 63.44$ \\
7 & Gigantochloa atter (Hassk.) Kurz & $511.88 \pm 331.81^{\text {a }}$ & $34.75 \pm 17.15$ & $149.50 \pm 99.70$ \\
8 & Gigantochloa robusta Kurz. & $689.83 \pm 277.05^{\text {a }}$ & $52.49 \pm 7.10$ & $220.00 \pm 84.00$ \\
9 & Gigantochloa verticillata (Willd.) Munro & $609.83 \pm 404.38^{\text {a }}$ & $36.60 \pm 5.72$ & $192.83 \pm 79.11$ \\
& P Value & 0.038 & 0.710 & 0.747 \\
\hline
\end{tabular}

Different lowercase letters indicate a significant difference between bamboo clamps using Duncan's multiple range test in ANOVA at $95 \%$ confidence interval.

The CCA resulted 4 axes, in which the combination of the two main axes is able to explain the relationship between the abundance of ferns and environmental variables of $84.74 \%$ of the total variance, with the proportion value of axis 1 and axis 2 of $47.55 \%$ and $37.19 \%$, respectively. The ordination chart showed that A. nidus, D. denticulata and V. ensiformis commonly found in bamboo clumps were located near the center of ordination, so that these species are able to grow and adapt to the different habitat conditions. A. nidus is generally be found in bamboo clumps with a large diameter, high number of culm, and high light intensity. Davallia denticulata tends to inhabit bamboo clumps which have a high number of culms with low culm height and low light intensity. Pyrrosia piloselloides tend to be fond of bamboo clumps with a low culm diameter and a high number of culms. The epiphytic fern that is rarely found, Goniophlebium percussum, has a strong correlation with the number of bamboo culms.

On the bamboo clumps, A. nidus, D. denticulata, and V. ensiformis are usually to be more perched on the aerial roots of basal culms. The larger the dbh diameter the wider the available aerial roots available. The wider the aerial roots, the greater the chance for the spores to perch on. These findings are consistent with the work of Zhang et al (2010), that the distribution of $A$. nidus within the forest is largely determined by moisture availability. The aerial roots of basal bamboo culms which are closer to the ground provide a more humid micro-habitat for A. nidus, $D$. denticulata, and $V$. ensiformis. A previous study has shown that A. nidus growth is more affected by water stress (Ainuddin and Najwa 2009). On palm trees, D. denticulata and V. ensiformis grow well and make dense populations in the basal zone (Praptosuwiryo et al. 2019).

The analysis of the abundance of ferns on the vertical gradient showed that the abundance of epiphytic ferns on the dominant bamboo is on the first interval $(0-1 \mathrm{~m})$ with an average value of 55.63 individuals/bamboo clums or $98.14 \%$ of the entire fern population found. Meanwhile, the vertical gradient level $2(1-2 \mathrm{~m})$ and level $3(2-3 \mathrm{~m})$ only have an abundance of less than one individual/bamboo clum. Results of the one-way ANOVA test showed that the abundance of ferns at several vertical gradients was significantly different $(\mathrm{P}<0.01)$, while based on the DMRT test, it was found that the abundance of ferns at level 1 was different from the abundance of level 2 and level 3 (Table 5). 
The first one-meter intervals of bamboo culms hosted all species of the epiphytic ferns. Three species, namely $P$. longifolia, $D$. denticulata and A. nidus were found only up to $2 \mathrm{~m}$ high. $P$. piloselloides and $M$. punctatum can grow at a vertical gradient up to level 3 . The results of the study are in agreement with the work of Magalhães and Lopes (2015) in tropical forests of Brazil, species of the Aspleniaceae, Lomariopsidaceae, and Pteridaceae that embellish trees are growing at a vertical gradient of $0-1.5 \mathrm{~m}$, while the member from the Polypodiaceae was growing at a vertical gradient of $0-2.5 \mathrm{~m}$. Pyrrosia piloselloides was the only species that grew until the highest intervals of height with a decreasing frequency from the bottom.

Table 5. Vertical distribution of epiphytic ferns growing on bamboo species.

\begin{tabular}{lcccccc}
\hline \multirow{2}{*}{ Species } & \multicolumn{3}{c}{ Abundance (indv./clump) } & \multicolumn{3}{c}{ Percent (\%) } \\
\cline { 2 - 7 } & Level 1 & Level 2 & Level 3 & Level 1 & Level 2 & Level 3 \\
\hline Asplenium nidus L. & 31.46 & 0.03 & 0.00 & 99.91 & 0.09 & 0.00 \\
Belvisia mucronata (Fée) Copel. & 0.03 & 0.00 & 0.00 & 100.00 & 0.00 & 0.00 \\
Davallia denticulata (Burm.) Mett. ex Kuhn & 14.77 & 0.17 & 0.00 & 98.85 & 1.15 & 0.00 \\
Goniophlebium percussum (Cav.) Wagner \& & 0.09 & 0.00 & 0.00 & 100.00 & 0.00 & 0.00 \\
Grether & 0.23 & 0.00 & 0.03 & 88.89 & 0.00 & 11.11 \\
Microsorum punctatum (L.) Copel. & 0.26 & 0.00 & 0.00 & 100.00 & 0.00 & 0.00 \\
Microsorum scolopendria (Burm. f.) Copel. & 0.91 & 0.00 & 0.00 & 100.00 & 0.00 & 0.00 \\
Nephrolepis biserrata (Sw.) Schott & 0.14 & 0.00 & 0.00 & 100.00 & 0.00 & 0.00 \\
Psilotum nudum (L.) Pal. Beauv. & 0.26 & 0.00 & 0.00 & 100.00 & 0.00 & 0.00 \\
Pyrrosia lanceolata (L.) Farw. & 0.51 & 0.26 & 0.00 & 66.67 & 33.33 & 0.00 \\
Pyrrosia longifolia (N. L. & 3.06 & 0.49 & 0.09 & 84.25 & 13.39 & 2.36 \\
Pyrrosia piloselloides (L.) Price & 3.91 & 0.00 & 0.00 & 100.00 & 0.00 & 0.00 \\
Vittaria ensiformis Swartz. & $\mathbf{5 5 . 6 3}^{\mathbf{b}}$ & $\mathbf{0 . 9 4}^{\mathbf{a}}$ & $\mathbf{0 . 1 1}^{\mathbf{a}}$ & $\mathbf{9 8 . 1 4}^{\mathbf{b}}$ & $\mathbf{1 . 6 6}^{\mathbf{a}}$ & $\mathbf{0 . 2 0}^{\mathbf{a}}$ \\
Sum & & & & & & \\
\hline
\end{tabular}

Different lowercase letters indicate a significant difference between bamboo clamps using Duncan's multiple rang test in ANOVA at $95 \%$ confidence interval.

The internodal surface texture of the bamboo is relatively smooth, but the aerial roots at nodes have a rough texture. The first interval from the basal bamboo has very dense aerial roots, so that the bottom texture is coarser than the vertical gradient above it. The coarser texture allows more spore capture and increasing the surface area for spore germination and gametophyte development. This observation showed that sporelings and young sporophytes were more often to be found at strata 1 (Fig. 2). It is indicated that the fern spores were much more trapped at the intervals 1 . The environmental factor affecting the vertical distribution of the fern is wind. Wind gusts will affect the movement of the bamboo culms. The intensity of the bamboo movement is getting higher with increasing vertical gradient, as a result, the possibility of releasing spores from their attachments are getting higher.

The highest specific richness at the first interval might be also related to the strategies used by epiphytic ferns for standing in more humid conditions. The species with the highest frequency and importance value (A. nidus) had a decreasing occurrence percentage from the lowest to the second intervals of height. $P$. piloselloides was the only species that grew until the highest intervals of height with a decreasing frequency from the bottom of bamboo culms. P. piloselloides is drought resistant as it can grow extensively in dry season with elongation rate of rihizome $3.3 \mathrm{~mm}$ long per day (Tsutsumi et al. 2018). This species is one of the most common epiphytes in the Malesian lowlands, from sea level to $1000 \mathrm{~m}$, that may overgrow entire tree and sometimes cause fatal 
effects (Hovenkamp et al. 1998), therefore it can be included into a facultative mild-hemiparasitic epiphyte (Tsutsumi et al. 2018).

\section{Acknowledgements}

This study was financially supported by Bogor Botanic Gardens, Research Center for Plant Conservation and Botanic Gardens, National Agency for Research and Innovation (BRIN).

\section{Acknowledgements}

This study was financially supported by Bogor Botanic Gardens, Research Center for Plant Conservation and Botanic Gardens, Indonesian Institute of Sciences (LIPI).

\section{References}

Adubasim CV, Akinnibosun HA, Dzekewong SN and Obalum SE 2018. Diversity and spatial distribution of epiphytic flora associated with four tree species of partially disturbed ecosystem in tropical rainforest zone. Agro-Science 17(3): 46-53. DOI: https://dx.doi.org/10.4314/as.v17i3.8.

Ainuddin NA and Najwa DAN. 2009. Growth and physiological responses of Asplenium nidus to water stress. Asian Journal of Plant Sciences 8(6): 447-450.

Ariati SR, Astuti RS, Supriatna I, Yuswandi AY, Setiawan A, Saftaningsih D and Pribadi DO. 2019. An Alphabetical List of Plant Species Cultivated in the Bogor Botanic Gardens. Center for Plant Conservation and Botanic Gardens - LIPI. Bogor.

Benzing DH. 1998. Vulnerabilities of tropical forests to climate change: the significance of resident epiphytes. Climate Change 39: 519-540.

Brighicna L, Montaini P, Favilli F and Trejo AC. 1992. Role of the nitrogen-fixing bacterial microflora in the epiphytism of Tillandsia (Bromeliaceae). American Journal of Botany 79: 723-727.

Buzas MA and Gibson TG. 1969. Species diversity: benthonic foraminifera in western North Atlantic. Science 163(3862): 72-75.

Curtis JT and McIntosh RP. 1950. The interrelations of certain analytic and synthetic phytosociological characters. Ecology 31(3): 435-455.

Dajoz R. 1977. Introduction to Ecology (translated by A. South). Hodder and Stoughton, London.

Einzmann HJR, Beyschlag J, Hofhansl F, Wanek W and Zotz G. 2015. Host tree phenology affects vascular epiphytes at thephysiological, demographic and community level. AoB PLANTS 7: plu073; doi:10.1093/aobpla/plu073

Fraga LL, Silva LB and Schmitt JL. 2008. Composição e distribuiçãovertical de pteridófi tas epifíticas sobre Dicksonia sellowiana Hook. (Dicksoniaceae), em fl oresta ombrófi la mista no sul do Brasil. Biota Neotropica 8(4): 123-129.

Hammer Ø, Harper DAT and Ryan PD. 2001. PAST: Paleontological Statistics Software Package for Education and Data Analysis. Palaeontologia Electronica 4(1): 9pp.

Holttum RE. 1966. A Revised Flora of Malaya. II. Ferns of Malaya. Gov Print Office, Singapore.

Hovenkamp PH, Bosman MTM, Hennipman E, Nooteboom HP, Rödl-Linder G and Roos MC. 1998. Polypodiaceae. Pp. 1-234. In: Kalkman and Nooteboom HP. Flora Malesiana Series II Vol. 3. Rijkherbarium/Hortus Botanicus, Leiden.

Jansen DH. 1976. Why bamboos wait so long to flower Annual? Annual Review of Ecology and Systematics 7(1): 347-391. DOI:10. 1146/annurev.es. 07.110176.002023.

Jiménez-López DA, Martínez-Camilo R, Martínez-Meléndez N and Kessler M. 2020. Diversity of epiphyte ferns along an elevational gradient in El Triunfo Biosphere Reserve, southern Mexico. Plant Ecology and Evolution 153(1): 12-21. https://doi.org/10.5091/plecevo.2020.1573.

Köppen W. 1936. Das Geographische System der Klimate (The Geographic System of Climates). Handbuch der Klimatologie. Borntraeger, Berlin. 
Kress WJ. 1986. The systematic distribution of vascular epiphytes: An update. Selbyana 9: 2-22.

Machado LS, Gonzatti F and Windisch PG. 2016. Epiphytic ferns in swamp forest remnants of the coastal plain of southern Brazil: latitudinal effects on the plant community. Acta Botanica Brasilica 30(4): 644657. doi: 10.1590/0102-33062016abb0319.

Magalhães JLL, Lopes MA. 2015. Species richness and abundance of low-trunk herb epiphytes in relation to host tree size and bark type, eastern Amazonia. Revista Árvore 39(3): 457-466.

Magurran AE. 2004. Measuring Biological Diversity. Blackwell Publishing, Oxford.

Nieder J, Prosperi J and Michaloud G. 2001. Epiphytes and their contribution to canopy diversity. Plant Ecology 153: 51-63.

Nitta JH, Watkins Jr JE and Davis CC. 2020. Life in the canopy: community trait assessments reveal substantial functional diversity among fern epiphytes. New Phytologist. doi: 10.1111/nph.16607.

Parashurama TR, Sushma K and Kariyajjanavar P. 2016. Host Variability of Drynaria quercifolia (L.) J.Sm. in Malnad Region, Karnataka, India. International Journal of Science and Research 5(1): 311-313.

Praptosuwiryo TNg, Sumanto and Cahyaningsih R. 2019. Diversity and host preferences of ferns and lycopods epiphytes on palm trees. Biodiversitas 20(12): 3731-3740. DOI: 10.13057/biodiv/d201236.

Putz FE. 1983. Liana biomass and leaf area of a "Tierra Firme" forest in the Rio Negro Basin, Venezuela. Biotropica 15(3): 185-189.

Santosa E, Widiyanto G, Lontoh AP, Agustin EK, Takahata K, Mine Y and Sugiyama N. 2014. Invasive weeds in Bogor Botanic Gardens, indonesia and its implication on surrounding landscapes. Buletin Kebun Raya 17(2): 113-126.

Schneider PH and Schmitt JL. 2011. Composition, community structure and vertical distribution of epiphytic ferns on Alsophila setosa Kaulf. In: Semideciduous Seasonal Forest, Morro Reuter, RS, Brazil. Acta Botanica Brasilica 25(3): 557-565.

Smith AR, Pryer KM, Schuettpelz E, Korall P, Schneider H and Wolf PG. 2008. Fern classification. In: Ranker TA, Haufler CH (eds.). Biology and Evolution of Ferns and Lycophytes. Cambridge University Press, Cambridge.

Terefe R, Jian L and Kunyong Y. 2019. Role of bamboo forest for mitigation and adaptation to climate change challenges in China. Journal of Scientific Research and Reports 24(1): 1-7.

Tsutsumi C, Praptosuwiryo TNg and Kato M. 2018. A preliminary study on mild hemiparasitic fern Pyrrosia piloselloides (Polypodiaceae). Bulletin of the National Museum of Nature and Science Ser B (Botany) 44(3): 121-125.

Veneklaas EJ and van Ek R. 1990. Rainfall interception in two tropical montane rain forests. Hydrological Processes 4: 311-326.

Viswanath S, Chethan K, Srivastava A, Joshi G, Sowmya C and Joshi SC. 2013. Dendrocalamus brandisii (Munro) Kurz. An ideal bamboo species for domestication in humid tropics. Institute of Wood Science and Technology Technical Bulletin No. 12.

Xing FW, Wang FG and Hovenkamp PH. 2013. Nephrolepidaceae. In: Flora of China, Vol. 2-3 (Pteridophytes), Wu ZY, Raven PH and Hong DY (eds), pp. 727-729. Science Press, Beijing \& Missouri Botanical Garden Press, St. Louis.

Zhang LB and Yatskievych G. 2013. Psilotaceae. In: Flora of China, Vol. 2-3 (Pteridophytes), Wu ZY, Raven PH and Hong DY (eds), p. 81. Science Press, Beijing \& Missouri Botanical Garden Press, St. Louis.

Zhang L, Nurvianto S and Harrison R. 2010. Factors affecting the distribution and abundance of Asplenium nidus L. in a tropical lowland rain forest in Peninsular Malaysia. Biotropica 42(4): 464-469.

Zotz G and Vollrath B. 2003. The epiphyte vegetation of the palm Socratea exorrhiza - Correlations with tree size, tree age and bryophyte cover. Journal of Tropical Ecology 19(1): 81-90.

Zotz G. 2016. Plants on Plants - The Biology of Vascular Epiphytes. Springer International Publishing, Switzerland.

(Manuscript received on 16 May, 2021; revised on 7 November, 2021) 